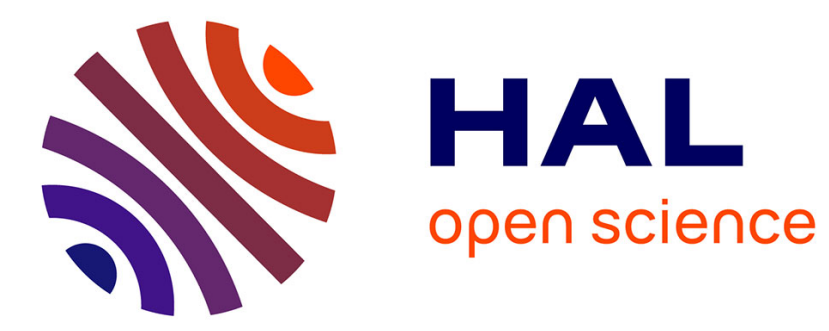

\title{
Fungus-growing termite foraging activity increases water infiltration but only slightly and temporally impacts soil physical properties in southern Indian woodlands
} Sougueh Cheik, Nicolas Bottinelli, Raman Sukumar, Pascal Jouquet

\section{- To cite this version:}

Sougueh Cheik, Nicolas Bottinelli, Raman Sukumar, Pascal Jouquet. Fungus-growing termite foraging activity increases water infiltration but only slightly and temporally impacts soil physical properties in southern Indian woodlands. European Journal of Soil Biology, 2018, 89, pp.20-24. hal-01955527

\section{HAL Id: hal-01955527 \\ https://hal.sorbonne-universite.fr/hal-01955527}

Submitted on 14 Dec 2018

HAL is a multi-disciplinary open access archive for the deposit and dissemination of scientific research documents, whether they are published or not. The documents may come from teaching and research institutions in France or abroad, or from public or private research centers.
L'archive ouverte pluridisciplinaire HAL, est destinée au dépôt et à la diffusion de documents scientifiques de niveau recherche, publiés ou non, émanant des établissements d'enseignement et de recherche français ou étrangers, des laboratoires publics ou privés. 


\title{
Fungus-growing termite foraging activity increases water infiltration but only slightly and temporally impacts soil physical properties in southern Indian woodlands
}

\author{
Sougueh Cheik ${ }^{\mathrm{a}, \mathrm{b}, *}$, Nicolas Bottinelli ${ }^{\mathrm{b}, \mathrm{c}}$, Raman Sukumar ${ }^{\mathrm{d}}$, Pascal Jouquet ${ }^{\mathrm{a}, \mathrm{b}}$ \\ a Indo-French Cell for Water Science (IFCWS), Civil Engineering Department, Indian Institute of Science, Bangalore, Karnataka, India \\ ${ }^{\mathrm{b}}$ Institute of Ecology and Environmental Sciences (UMR 242 iEES Paris), Institute of Research for Development, Bondy, France \\ ${ }^{\mathrm{c}}$ Soils and Fertilizers Research Institute (SFRI), Dong Ngac, Tu Liem, Ha Noi, Viet Nam \\ ${ }^{\mathrm{d}}$ Center of Ecological Sciences, Institute of Science, Bangalore, Karnataka, India
}

\begin{abstract}
A B S T R A C T
In the tropics, termites are known to be key litter decomposers and soil bioturbators. Their foraging activity in the soil leads to the production of galleries with specific soil physical, chemical and biological properties. This study investigates the influence of these foraging galleries on water infiltration and soil properties in southIndian woodlands. A significant increase in water infiltration ( $\times 3$ that of control plots) was measured in soil as a result of Odontotermes spp. activities, likely because of the production of galleries in the first $\mathrm{cm}$ of the soil. Termite foraging activity was also associated with a significantly greater amount of clay in soil, probably because termites cover the wall of their galleries with fine-size particles, resulting in an increased saturated soil water content. Conversely, no differences in $\mathrm{C}$ content, $\mathrm{CO}_{2}$ emission and soil bulk density were measured in comparison with the surrounding soil. Consequently, this study confirms the beneficial impact of termites on water infiltration in soil but suggests a rather low local impact on soil chemical and biological functioning.
\end{abstract}

\section{Introduction}

A substantial body of literature suggests that human societies derive many essential environmental goods and services from biodiversity [1-3]. In this context, the study of the ecological impacts of soil biodiversity has become a priority for the definition of sustainable agricultural practices [4]. This challenge is particularly exacerbated in various tropical regions of the world by the fact that many species remain unknown and/or endangered by the degradation of natural habitat $[2,5,6]$.

In the tropics, arthropods, particularly insects, make up the majority of known biodiversity [5,6]. In these environments, termites (Isoptera) are considered key soil physical engineers or bioturbators (sensu $[7,8]$ ) because they influence many ecological processes such as the decomposition of litter on the ground, the regulation of soil organic matter (SOM) and nutrient cycling, the infiltration and storage of water in the soil, the erosion of soil, and the regulation of plant growth and diversity [7,9-12]. Thus, because of their large abundance and their impact on a large number of ecological functions, termites are considered to play a role similar to that of earthworms in arid and sub-arid tropical ecosystems [13]. However, this comparison between earthworms and termites remains speculative in most of the cases and there is a paucity of information on the influence of termite on soil biostructures (sheetings, mound nests) and biopores (galleries, subterranean chambers) in most tropical ecosystems, especially if we compare to the large amount of information available on the impact of earthworms on soil porosity and water dynamic in temperate ecosystems (e.g. [14,15]).

In Southern Indian forests, fungus-growing termites (Macrotermitiane subfamily) are key actors of litter decomposition $[16,17]$. They produce above- and below-ground nest structures and sheetings covering the litter that is consumed with specific soil physical and chemical properties in comparison with the surrounding soil environment, then impacting soil fertility and erosion at the ecosystem scale [18-20]. Fungus-growing termites also produce galleries in soil that are used for foraging and bringing the litter from the ground to their nests. However, although the properties of their soil sheetings have been described (e.g. Refs. [21,22]), the influence of their galleries on soil functioning, and especially water and SOM dynamics, remains limited to studies carried out in Sahelian soils where they increase soil porosity, water infiltration and water storage, and reduce crust

\footnotetext{
* Corresponding author. Indo-French Cell for Water Science (IFCWS), Civil Engineering Department, Indian Institute of Science, Bangalore, Karnataka, India. E-mail address: sougueh33@hotmail.fr (S. Cheik).
} 
formation, water runoff and soil erosion [23-26]. Consequently, the aim of this study was to determine if termites also influence water infiltration and soil properties in south Indian woodlands through the production of galleries, as observed in African savannas. Our hypothesis was that the foraging activity of termites is associated to a modification of the soil biological, chemical and physical properties in comparison with the surrounding soil, and especially a higher water infiltration rate.

\section{Materials and methods}

\subsection{Study site and soil sampling}

This study was carried out during the dry season (February-March) in 2016 in the forest of the Jubilee Garden in the Indian Institute of Science (IISc, $13^{\circ} 01^{\prime} 18^{\prime \prime} \mathrm{N}$ and $77^{\circ} 34^{\prime} 14^{\prime \prime} \mathrm{E}$ ) in Bangalore city, Karnataka state, India. The vegetation is a planted deciduous forest dominated by Acacia trees, mainly Acacia auriculiformis. This ecosystem has a tropical savannah climate with distinct wet and dry seasons, and the annual rainfall ranges from 900 to $1100 \mathrm{~mm} \mathrm{yr}^{-1}$ [27]. The soil is described as Alfisol in the US Soil Taxonomy (USDA) or Luvisol according to FAO classification. The clay fraction is mainly kaolinite and soil $\mathrm{pH}$ is 5.7.

In this study site, litter-feeding termites are mainly Odontotermes feae, O. obesus and $O$. feoides [27]. These species are commonly found in South India [28]. Their activity is associated to the presence of soil sheeting on wood logs or fallen leaves on the ground. Hence, the influence of termites on soil properties was assessed in comparing the properties of the soil sampled from 0 to $5 \mathrm{~cm}$ depth without visible recent activity of termites (CTRL) to the soil below logs covered by termite sheeting (T). A differentiation was made between samples where termites were observed feeding on the wood $\left(\mathrm{T}_{\text {new }}\right)$ and samples where termites were not observed and then considered to be old or unused $\left(\mathrm{T}_{\text {old }}\right)$.

\subsection{Soil hydraulic conductivity}

Water infiltration was measured with the beerkan method [29] with a cylinder having an inner diameter of $11 \mathrm{~cm}$. The surface litter was gently removed over an area slightly larger than the cylinder diameter, while the soil was untouched. The cylinder was positioned at the soil surface and inserted to a depth of $2-3 \mathrm{~cm}$ to prevent lateral losses of water. A fixed volume of water $(100 \mathrm{~mL}$, corresponding to a water depth of $1 \mathrm{~cm}$ ) was initially poured into the cylinder, and the time needed for the water to infiltrate was recorded. As soon as the first volume had completely infiltrated, another equal volume of water was added to the cylinder and the time for this volume to infiltrate (cumulative time) was recorded. The procedure was repeated until reaching steady state conditions, usually after 12 to 15 consecutive infiltration times. In this way, a cumulative infiltration, $I(\mathrm{~mm})$, versus time, $t$ (sec), relationship including $N_{i}$ discrete points $\left(t_{i}, I_{i}\right)$ was determined. This value was used to derive field-saturated hydraulic conductivity $\left(K_{f s}\right.$ in $\left.\mathrm{mm} \mathrm{s}^{-1}\right)$ using the formula described by Ref. [30]:

$K_{f s}=\frac{b_{1}}{0.467\left(\frac{2.92}{r \times \alpha^{*}}+1\right)}$

Where $b_{1}$ corresponds to the slope of the linear relation $\frac{I}{t^{0.5}}=f\left(t^{0.5}\right)$ (in $\mathrm{mm} \mathrm{s}^{-1}$ ) and $r$ to the ring radius (in $\mathrm{mm}$ ). A value of $\alpha^{*}$ $=0.012 \mathrm{~mm}^{-1}$ was chosen as suggested by Ref. [31] for soils with intermediate clay values.

Once the steady state was reached, a volume of $300 \mathrm{~mL}$ of water dyed with methylene blue $\left(\sim 0.3 \mathrm{~g} \mathrm{~L}^{-1}\right)$ was poured in the cylinder for measuring the functional porosity and investigate water pathways [32]. The soil in the centre of the cylinder was then sampled using a smaller cylinder (5.7 diam x $5 \mathrm{~cm}$ high). Samples were weighted humid and airdied during 2-3 days. The first $\mathrm{mm}$ of the soil samples were gently scratched in order to assess the preferential flow paths that were dyed in blue. Soil samples were thereafter carefully cut at $1,2.5$ and $4 \mathrm{~cm}$ depth and a picture was taken for each of these depths (see supplementary file for an illustration). The surface of the soil dyed in blue was then manually delimited and measured (in \%) at 0, 1, 2.5, 4 and $5 \mathrm{~cm}$ depth using Image $J$ software. Soil water content after the infiltration experiment was measured in weighting soil samples after sampling and after drying them at $110^{\circ} \mathrm{C}$ during $48 \mathrm{~h}$ and considered thereafter as saturated soil water content. The number of replicates was $n=10$.

\subsection{Soil analyses}

Soils were sampled outside of the cylinder for measuring their physical and chemical properties. SOM was assessed from carbon concentration with a TOC analyzer (model SSM-5000A) using a SHIMADZU TOC $\mathrm{V}_{\mathrm{CSH}}$ analyzer. Soil particle size distribution was measured after destruction of organic matter using $\mathrm{H}_{2} \mathrm{O}_{2}$ and complete soil dispersion with Na-hexametaphosphate $\left(20 \mathrm{~g} \mathrm{~L}^{-1}\right.$, AFNOR, NFX 31107) in an ultrasonic bath during $15 \mathrm{~min}$. Particles were then wet-sieved and particles $<20 \mu \mathrm{m}$ were determined using a laser particle size analyzer. Soil bulk density was measured using cylinders $(5.7 \mathrm{~cm}$ diam $\times 5 \mathrm{~cm}$ high) and after drying at $105^{\circ} \mathrm{C}$ during 2 days. Undisturbed soil samples were also collected using the same cylinders and incubated in the dark in hermetic boxes $\left(13 \mathrm{~cm}\right.$ diameter x $14 \mathrm{~cm}$ high) at $28-30{ }^{\circ} \mathrm{C}$ and $80 \%$ of the water holding capacity during 44 days. $\mathrm{C}-\mathrm{CO}_{2}$ emission was measured after $1,4,7,14,21,29,37$ and 44 days through a vial containing $5 \mathrm{~mL}$ aqueous $\mathrm{NaOH}$ solution $(0.5 \mathrm{M})$ to trap the $\mathrm{CO}_{2}$ emitted. The $\mathrm{C}^{-} \mathrm{CO}_{2}$ produced was determined by back titration $(\mathrm{HCl}$ $0.2 \mathrm{M}$; pH 8.6) of the $\mathrm{NaOH}$ trap with excess $\mathrm{BaCl}_{2}(1.5 \mathrm{M})$ using a DL 50 - potentiometric titrator. The numbers of replicates was $n=5$, except for the measure of the soil bulk density where 10 replicates were considered.

\subsection{Statistical analyses}

The normal distribution of residues was tested using the ShapiroWilk test. Analysis of variance (ANOVA) and LSD tests were performed to assess differences between means. Kruskal-Wallis Chi-squared and Wilcoxon-Mann-Whitney $\mathrm{U}$ tests post-hoc planned pairwise comparisons were performed with a false discovery rate correction when parametric analysis of variance was impossible to use, even after data transformation. All statistical calculations were carried out using $\mathrm{R}$ and RStudio (version i386 3.2.5). Differences among treatments were declared significant at the $<0.05$ probability level.

\section{Results}

\subsection{Soil properties}

Results concerning the influence of termites on soil physical and chemical properties are shown in Table 1 . No significant difference in bulk density, respiration and $\mathrm{C}$ concentration was measured between

Table 1

Results of the ANOVA testing the influence of termite foraging activity (CTRL, $\mathrm{T}_{\text {new }}$ or $\mathrm{T}_{\text {old }}$ ) on the sand, clay and C contents (\%); soil respiration (amount of C$\mathrm{CO}_{2}$ emitted over 44 days, in $\mu \mathrm{g} g$ soil ${ }^{-1}$ ) and saturated soil water content (in $\%)\left(\mathrm{n}=5 \mathrm{in}\right.$ all cases) as well as on soil bulk density $\left(\mathrm{g} \mathrm{cm}^{-3}, \mathrm{n}=10\right)$.

\begin{tabular}{llc}
\hline & $F$ & $P$-value \\
\hline Sand & $F_{2,12}=6.96$ & 0.010 \\
Clay & $F_{2,12}=6.06$ & 0.015 \\
C content & $F_{2,12}=0.18$ & 0.834 \\
Soil bulk density & $F_{2,26}=0.42$ & 0.663 \\
Soil respiration & $F_{2,12}=1.10$ & 0.364 \\
Saturated soil water content & $F_{2,12}=76.94$ & $<0.001$ \\
\hline
\end{tabular}




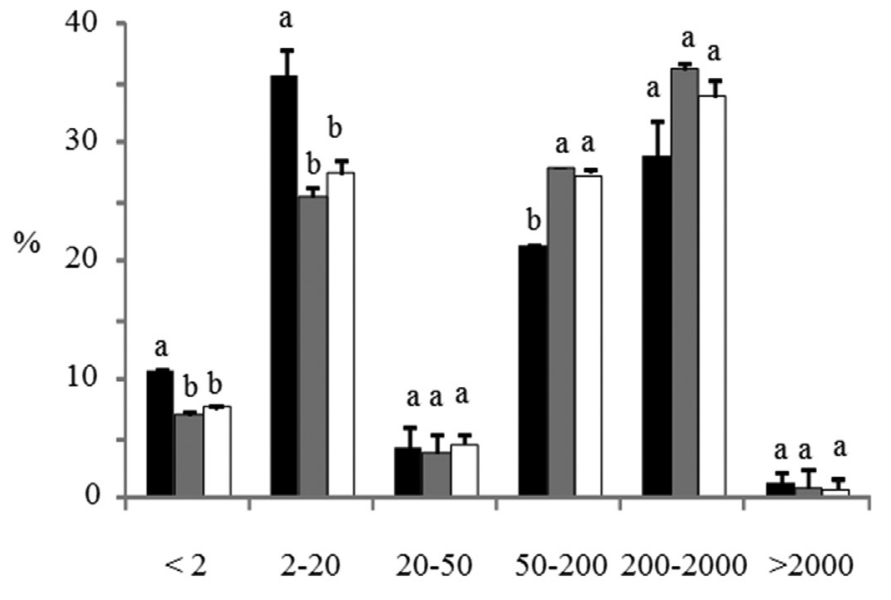

Particle size $(\mu \mathrm{m})$

Fig. 1. Particle size distribution of soil samples. Treatments are control (CTRL, in white) and soil influenced by termite activity ( $\mathrm{T}_{\text {new }}$, in black, and $\mathrm{T}_{\text {old }}$, in grey) $(n=5)$. Bars are standard errors. Treatments were compared for each particle size class, and histograms with the same letters are similar at $P=0.05$.

treatments, with $P$-values $>0.05$ in all cases. Conversely, termite foraging activity was significantly associated with a modification of the particle size distribution, with greater small-sized particle $(<2$ and $2-20 \mu \mathrm{m})$ contents and fewer large-sized particles $(50-2000 \mu \mathrm{m})$ in $\mathrm{T}_{\text {new }}$ than in $\mathrm{T}_{\text {old }}$ and CTRL $(P<0.05$ in both cases) (Fig. 1). Interestingly, no significant difference was measured between $\mathrm{T}_{\text {old }}$ and CTRL $(P>0.05)$. A greater saturated soil water content was also measured in $\mathrm{T}_{\text {new }}(57.2 \%$, standard error $(\mathrm{SE})=2.2)$ than in $\mathrm{T}_{\text {old }}$ and CTRL (36.4 and $33.7 \%, \mathrm{SE}=1.1$ and 0.6 , respectively $)(P<0.05)$. No significant difference was measured between $\mathrm{T}_{\text {old }}$ and CTRL $(P>0.05)$.

\subsection{Soil porosity and water infiltration}

$K_{f s}$ was significantly enhanced by the activity of termites (ANOVA, $F_{2,26}=6.86, P=0.004$ ) (Fig. 2). Greater $K_{f s}$ was measured in $\mathrm{T}_{\text {new }}$ in comparison with CTRL $(P<0.05)$, while a more intermediate value was reached for $\mathrm{T}_{\text {old }}$ in comparison with $\mathrm{T}_{\text {new }}$ and CTRL $(P>0.05$ in both cases).

Fig. 3 shows that termite foraging activity was associated with a significantly greater surface of dyed soil in the $T_{\text {new }}$ treatment. The results were significant from 1 to $5 \mathrm{~cm}$ depth $(P<0.05)$, but the

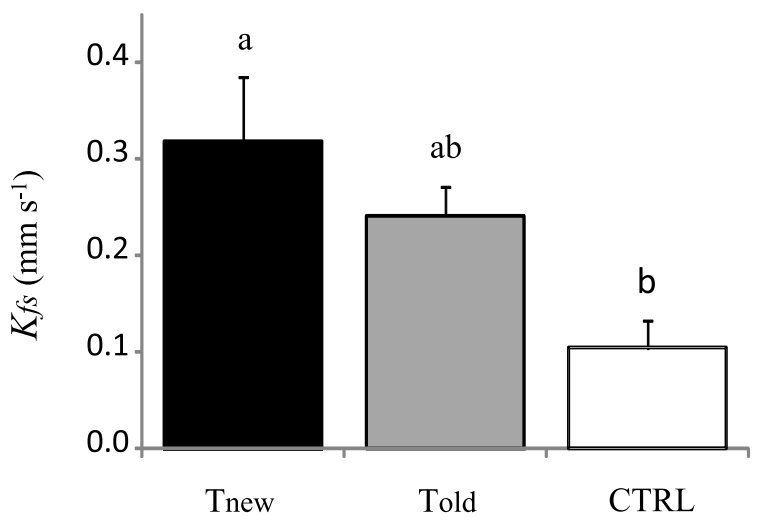

Treatments

Fig. 2. Field-saturated hydraulic conductivity $\left(K_{f \mathrm{~s}}\right.$ in $\left.\mathrm{mm} \mathrm{s}^{-1}\right)$ in soil influenced by termite foraging activity $\left(\mathrm{T}_{\mathrm{new}}\right.$, in black, and $\mathrm{T}_{\text {old }}$, in grey) and in the control surrounding soil environment (CTRL). Histograms with the same letters are not significantly different at $P=0.05$. Bars are standard errors, $\mathrm{n}=10$.

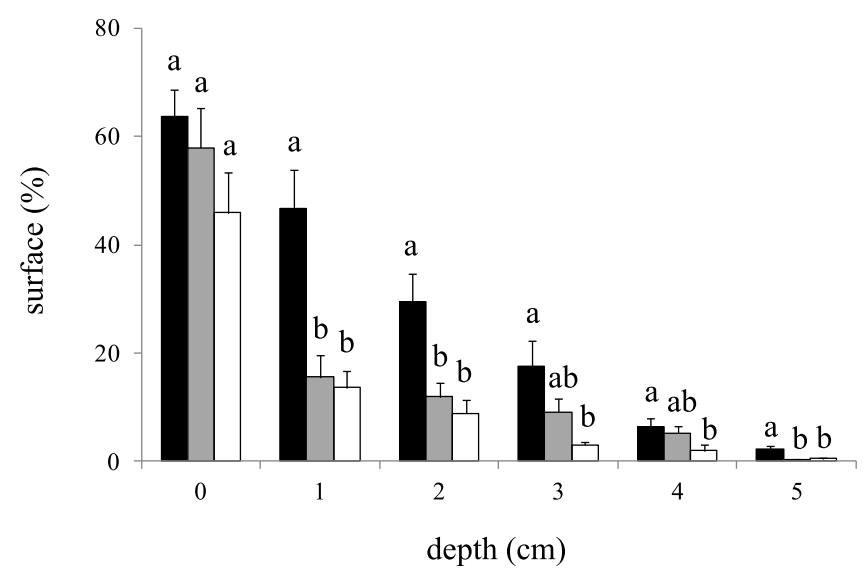

Fig. 3. Soil surface covered by methylene blue (\%). Treatments are control (CTRL, in white) and soil influenced by termite activity (Tnew, in black, and Told, in grey) $(\mathrm{n}=10)$. Bars are standard errors.

differences between $\mathrm{T}_{\text {new }}$ and CTRL were more important from 1 to $3 \mathrm{~cm}$ depth.

\section{Discussion}

\subsection{Impact of termite foraging activity on soil properties}

Termites are known to incorporate clay and carbon, either as faeces or salivary secretions, in their constructions [10,11]. In our study, termite foraging activity was also associated with a modification of the particle size distribution in soil, with greater small-sized particle $(<20 \mu \mathrm{m})$ contents and fewer large-sized particles $(>50 \mu \mathrm{m})$ in $\mathrm{T}_{\text {new }}$ than in CTRL. This enrichment in fine-sized particles was associated with significantly greater saturated soil water content, which is likely to be beneficial to termites that are poorly resistant to drought. This interpretation is consistent with studies carried out in Africa, where fungus-growing termites enrich their constructions in clay particles because this material offers a greater water-holding capacity and increases the resistance of their constructions to water [33-36]. It is likely that the walls of the galleries were also covered by salivary secretions in our study, as observed, for instance, for the walls of belowground fungus-comb chambers in Africa [37]. Therefore, we assume that the non-significant differences in $\mathrm{C}$ content and $\mathrm{CO}_{2}$ emission can be explained either by the rapid mineralization of salivary $\mathrm{C}$ in soil and/or our sampling procedure. Indeed, although of significant importance, it is likely that the soil covering the galleries represented only a small proportion of the soil contained in the $128 \mathrm{~cm}^{3}$ soil sample, thus making this $\mathrm{C}$ enrichment undetectable at larger scale.

Finally, our study also showed that the greater clay and lesser sand contents associated with the termite tunnelling activity only lasted during the period of activity of termites, since $\mathrm{T}_{\text {old }}$ had more similar properties than CTRL. This result suggests that termites' impact on soil functioning is only limited to the period of foraging, in agreement with $[23,38]$, who showed that the impact of termites is rather limited to a temporary modification of the soil particle size distribution.

\subsection{Influence of termites on saturated hydraulic conductivity}

In their review, Lamoureux et al. [39] considered that hydraulic conductivity is the only soil parameter that is significantly impacted by termite foraging activity. However, the influence of termites on water infiltration has been evidenced almost solely in African savannas and to a lesser extent in Australian savannas, where the application of mulch is associated with a stimulation of termite activity, which in turn increases soil macroporosity and water infiltration [23,40-42]. Despite 
the fact that termites are conspicuous features of forest ecosystems, especially in India, where they actively contribute to wood decomposition [17], we are aware of no study focusing on their impact on soil porosity and water infiltration in this type of environment. Our results suggest that $K_{f s}$ was significantly enhanced by the activity of termites, thus confirming results obtained earlier in Africa and Australia. This more elevated saturated hydraulic conductivity $(\times 3)$ is explained by the tunnelling activity of termites, which produces galleries or "channels" that might constitute preferential flow paths in soil $[24,25]$.

Conversely to earthworm galleries that have been deeply studied in terms of structure and impact on water infiltration [14,43], and to a lesser extent in terms of lifetime [44], there is a clear paucity of information on termite foraging galleries and especially on their lifetime and on the volume of soil they occupy. In our study, the more intermediate value reached for $\mathrm{T}_{\text {old }}$ in comparison with $\mathrm{T}_{\text {new }}$ and CTRL ( $P>0.05$ in both cases) suggests that the positive influence of termites on water infiltration persists temporarily beyond their period of activity. The more important diffusion of water through termite galleries was also evidenced with the utilization of methylene blue water. Although these results have to be considered with caution since it is also plausible that the enhanced surface of dyed soil was related to the enhanced sorption due to increased clay content in $T_{\text {new }}$, they suggest (i) that termite foraging bio-pores did not resist the pressure exerted by the continuous addition of water and (ii) that termite foraging activity mainly occurred in the first $\mathrm{cm}$ of the soil. Finally, intermediate values to $\mathrm{T}_{\text {new }}$ and CTRL were measured for $\mathrm{T}_{\text {old }}$, thus confirming the need to better understand the lifetime of galleries in soil once termites do not use them anymore as well as their resistance to the diffusion of water in soil.

\section{Conclusion}

This study confirmed the positive impact of termites on water infiltration in soil, especially through the production of superficial tunnels that are likely to act as preferential flow paths. However, this study also raised the question of the resistance of galleries to water and consequently of their lifetime in soil. It also showed that, despite a significant enhancement in clay particles in soil, the effect of termite foraging activity had no significant effect on soil chemical and biological properties at the soil core scale. Finally, we suggest that more research is needed in other environments, such as croplands and/or more natural environments (e.g. Indian Tiger Reserve), to confirm the results of this study, which was carried out in a planted forest in the centre of a city.

\section{Acknowledgments}

We would like to thank Prof. S. Subramanian, R.J. Deshpande, B. Soudan, A. Pando and J. Riotte for their support and for allowing us to have access to facilities from IISc. This project was supported by the French National Program EC2CO-Biohefect "MACROFLUX" and benefited from funding from the Indo-French Cell for Water Science (LMI CEFIRSE, http://www.cefirse.ird.fr).

\section{Appendix A. Supplementary data}

Supplementary data related to this article can be found at https:// doi.org/10.1016/j.ejsobi.2018.09.001.

Supplementary file Photo showing preferential flow paths for water where soil was dyed blue by the methylene blue solution.

\section{References}

[1] M.G. Kibblewhite, K. Ritz, M.J. Swift, Soil health in agricultural systems, Philos. Trans. R. Soc. Lond. B Biol. Sci. 363 (2008) 685-701.

[2] T. Decaëns, J.J. Jimenez, C. Gioia, G.J. Measey, P. Lavelle, The values of soil animals for conservation biology, Eur. J. Soil Biol. 42 (2006) 23-38.

[3] E. Barrios, Soil biota, ecosystem services and land productivity, Ecological Economics - Ecosystem Services and Agriculture, Ecosyst. Serv. 64 (2007) 269-285.

[4] M.A. Altieri, The ecological role of biodiversity in agroecosystems, Agric. Ecosyst. Environ. 74 (1999) 19-31.

[5] C. Fragoso, G. Brown, J.C. Patrón, E. Blanchart, P. Lavelle, B. Pashanasi, T. Kumar, Agricultural intensification, soil biodiversity and agroecosystem function in the tropics: the role of earthworms, Appl. Soil Ecol. 6 (1997) 17-35.

[6] H.I.J. Black, M.J.N. Okwakol, Agricultural intensification, soil biodiversity and agroecosystem function in the tropics: the role of termites, Appl. Soil Ecol. 6 (1997) 37-53.

[7] P. Lavelle, D. Bignell, M. Lepage, W. Wolters, P. Roger, P.O.W.H. Ineson, S. Dhillion, Soil function in a changing world: the role of invertebrate ecosystem engineers, Eur. J. Soil Biol. 33 (4) (1997) 159-193.

[8] P. Jouquet, S. Traoré, C. Choosai, C. Hartmann, D. Bignell, Influence of termites on ecosystem functioning, Ecosystem services provided by termites, Eur. J. Soil Biol. 47 (4) (2011) 215-222 2011.

[9] L.A. Lobry de Bruyn, A.J. Conacher, The role of termites and ants in soil modification-a review, Soil Res. 28 (1) (1990) 55-93.

[10] J.A. Holt, M. Lepage, Termites and Soil Properties in Termites: Evolution, Sociality, Symbioses, Ecology, Springer, Dordercht, 2000, pp. 389-407.

[11] P. Jouquet, N. Bottinelli, R.R. Shanbhag, T. Bourguignon, S. Traoré, S.A. Abbasi, Termites: the neglected soil engineers of tropical soils, Soil Sci. 181 (2016) $157-165$

[12] D.E. Bignell, Termites as soil engineers and soil processors, Intestinal Microorganisms of Termites and Other Invertebrates, Springer Berlin Heidelberg, 1981, pp. 183-220.

[13] P. Jouquet, E. Chaudhary, A.R.V. Kumar, Sustainable use of termite activity in agroecosystems with reference to earthworms, A review. Agron. Sustain. Dev. 38 (1) (2018) 3 .

[14] Y. Capowiez, N. Bottinelli, S. Sammartino, E. Michel, P. Jouquet, Morphological and functional characterisation of the burrow systems of six earthworm species (Lumbricidae), Biol. Fertil. Soils 51 (2015) 869-877.

[15] N. Bottinelli, H. Zhou, Y. Capowiez, Z. Zhang, Q. Jiangping, P. Jouquet, X. Peng, Earthworm burrowing activity of two non-Lumbricidae earthworms species incubated in soils with contrasting organic carbon content (Vertisol vs. Ultisol), Biol. Fertil. Soils 53 (2017) 951-955.

[16] B. Ferry, Distribution of the important litter decomposing termites (Isoptera) in the Western Ghats forests of Karnataka (India), Pedobiologia 36 (4) (1992) 193-211.

[17] R.R. Shanbhag, R. Sundararaj, Host range, pest status and distribution of wood destroying termites of India, J. Trop. Asian Entomol. 2 (2013) 12-27.

[18] N.G. Kumar, Studies on the Ecology of the Subterranean Termite, Odontotermes horni (Wasmann) (Isoptera: Termitidae) and its Foraging Effects on the Soil Nutrient Status, Agricultural Entomology, Bangalore, India, PhD thesis University of Agricultural Sciences, 1991, p. 258.

[19] P. Jouquet, N. Guilleux, S. Chintakunta, M. Mendez, R.R. Shanbhag, The influence of termites on soil sheeting properties varies depending on the materials on which they feed, Eur. J. Soil Biol. 69 (2015) 74-78.

[20] P. Jouquet, N. Guilleux, L. Caner, S. Chintakunta, M. Ameline, R. Shanbhag, Influence of soil pedological properties on termite mound stability, Geoderma 262 (2016) 45-51.

[21] A. Harit, R. Shanbhag, E. Chaudhary, S. Cheik, P. Jouquet, Properties and functional impact of termite sheetings, Biol. Fertil. Soils 53 (2017) 743-749.

[22] A. Harit, H. Moger, J.L. Duprey, S.A. Abbasi, S. Subramanian, P. Jouquet, Termites can have greater influence on soil properties through the construction of soil sheetings than the production of above-ground mounds, Insectes Soc. 67 (2017) 247-253.

[23] A. Mando, L. Stroosnijder, L. Brussaard, Effects of termites on infiltration into crusted soil, Geoderma 74 (1) (1996) 107-113.

[24] J. Léonard, J.L. Rajot, Influence of termites on runoff and infiltration: quantification and analysis, Geoderma 104 (1) (2001) 17-40.

[25] J. Léonard, E. Perrier, J.L. Rajot, Biological macropores effect on runoff and infiltration: a combined experimental and modelling approach, Agric. Ecosyst. Environ. 104 (2004) 277-285.

[26] D. Kaiser, M. Lepage, S. Konaté, K.E. Linsenmair, Ecosystem services of termites (Blattoidea: termitoidae) in the traditional soil restoration and cropping system Zai in northern Burkina Faso (West Africa), Agric. Ecosyst. Environ. 236 (2017) $198-211$.

[27] P. Jouquet, N. Guilleux, S. Chintakunta, M. Mendez, R.R. Shanbhag, The influence of termites on soil sheeting properties varies depending on the materials on which they feed, Eur. J. Soil Biol. 69 (2015) 74-78.

[28] R.R. Shanbhag, R. Sundararaj, Host range, pest status and distribution of wood destroying termites of India, J. Trop. Asian Entomol. 2 (2013) 12-27.

[29] I. Braud, D. De Condappa, J.M. Soria, R. Haverkamp, R. Angulo-Jaramillo, S. Galle, M. Vauclin, Use of scaled forms of the infiltration equation for the estimation of unsaturated soil hydraulic properties (the Beerkan method), Eur. J. Soil Sci. 56 (3) (2005) 361-374.

[30] V. Bagarello, S. Di Prima, M. Iovino, G. Provenzano, Estimating field-saturated soil hydraulic conductivity by a simplified Beerkan infiltration experiment, Hydrol. Process. 28 (2014) 1095-1103.

[31] D.E. Elrick, W.D. Reynolds, Methods for analyzing constant-head well permeameter data, Soil Sci. Soc. Am. J. 56 (1992) 320-323.

[32] M. Flury, N.N. Wai, Dyes as tracers for vadose zone hydrology, Rev. Geophys. (1) (2003) 412003.

[33] S. Konaté, X. Le Roux, D. Tessier, M. Lepage, Influence of large termitaria on soil characteristics, soil water regime, and tree leaf shedding pattern in a West African 
savanna, Plant Soil 206 (1999) 47-60.

[34] P. Jouquet, M. Lepage, B. Velde, Termite soil preferences and particle selections: strategies related to ecological requirements, Insectes Soc. 49 (1) (2002) 1-7.

[35] P. Jouquet, D. Tessier, M. Lepage, The soil structural stability of termite nests: role of clays in Macrotermes bellicosus (Isoptera, Macrotermitinae) mound soils, Eur. J. Soil Biol. 40 (2004) 23-29.

[36] L. Abbadie, M. Lepage, The role of subterranean fungus comb chambers (Isoptera, Macrotermitinae) in soil nitrogen cycling in a preforest savanna (Cote d'Ivoire), Soil Biol. Biochem. 21 (8) (1989) 1067-1071.

[37] P. Jouquet, T. Mery, C. Rouland, M. Lepage, Modulated effect of the termite Ancistrotermes cavithorax (Isoptera, Macrotermitinae) on soil properties according to the internal mound structures, Sociobiology 42 (2) (2003) 403-412.

[38] T.W. Awadzi, M.A. Cobblah, H. Breuning-Madsen, The role of termites in soil formation in the tropical semi-deciduous forest zone, Ghana, Geogr, Tidsskr-Den. 104 (2) (2004) 27-34.
[39] S. Lamoureux, M.A. O'Kane, Effects of termites on soil cover system performance, Dalam Fourie dan Tibbet, in: H. Perth (Ed.), Mine Clossure, 2012, pp. 433-446.

[40] N.Z. Elkins, G.V. Sabol, T.J. Ward, W.G. Whitford, The influence of subterranean termites on the hydrological characteristics of a Chihuahuan desert ecosystem, Oecologia 68 (4) (1986) 521-528.

[41] T.Z. Dawes, Impacts of habitat disturbance on termites and soil water storage in a tropical Australian savanna, Pedobiologia 53 (4) (2010) 241-246.

[42] A. Mando, L. Brussaard, L. Stroosnijder, Termite-and mulch-mediated rehabilitation of vegetation on crusted soil in west Africa, Restor. Ecol. 7 (1) (1999) 33-41.

[43] Y. Capowiez, N. Bottinelli, P. Jouquet, Quantitative estimates of burrow construction and destruction by anecic and endogeic earthworms in repacked soil cores, Appl. Soil Ecol. 74 (2014) 46-50.

[44] N. Bottinelli, T. Henry-des-Tureaux, V. Hallaire, Y. Benard, J. Mathieu, T. Duc Tran, P. Jouquet, How earthworms accelerate soil porosity under watering events, Geoderma 156 (1-2) (2010) 43-47 2010. 